\title{
Virtual exchange: a promising high-impact practice for developing intercultural effectiveness across disciplines
}

\author{
Nannette Evans Commander ${ }^{1}$, Wolfgang F. Schloer ${ }^{2}$, and Sara T. Cushing ${ }^{3}$
}

Abstract

T irtual Exchange (VE), a pedagogy that uses technology to facilitate online, collaborative work among students and their peers in other countries, is viewed as a high-impact practice contributing to engaged learning and student success in higher education. This study investigates the impact of various types of VE on the intercultural effectiveness skills of undergraduate and graduate students enrolled in courses across disciplines. The relationship between VE and intercultural skills for minority and non-minority students was also investigated, along with the relationship between dosage (length and duration) of VE and intercultural skills. Results indicate VE positively impacts the development of intercultural skills of students and that there were no differences when the data are disaggregated by individual classes or disciplinary areas. There were no significant differences for minority and non-minority students and for the impact of dosage, but further research is recommended for these two important topics. Findings of this study underline the generalizability of VE across disciplines and its suitability for providing wider access to international experiences for all students.

Keywords: virtual exchange; high-impact practices; intercultural effectiveness; digital competence; online communication.

1. Georgia State University, USA, ncommander@gsu.edu; https://orcid.org/0000-0001-9930-4810

2. Georgia State University, USA; wschloer@gsu.edu; https://orcid.org/0000-0001-8105-6337

3. Georgia State University, USA; stcushing@gsu.edu; https://orcid.org/0000-0002-5804-700X

How to cite this article: Commander, N. E., Schloer, W. F., \& Cushing, S. T. (2022). Virtual exchange: a promising high-impact practice for developing intercultural effectiveness across disciplines. Journal of Virtual Exchange, 5, 1-19. https://doi.org/10.21827/jve.5.37329 


\section{VE: a promising high-impact practice for developing intercultural effectiveness across disciplines}

The COVID-19 pandemic, one of the most severe crises of our time, is causing massive disruptions to all segments of society around the world. Higher education is certainly no exception, and universities are facing multiple challenges as campuses across the country adjust to changing conditions and faculty strive to embrace new instructional models as they adapt ways of teaching for online learning. While many faculty prefer traditional face-to-face teaching methods, they are quickly customizing technologies to their individual pedagogic philosophies and working to keep students engaged. With less physical mobility and education more digital than ever before, this unprecedented time underlines the adage, 'when a door closes, a window opens'. The transformation of higher education caused by the pandemic creates new opportunities in multiple areas.

One important opportunity for consideration is the delivery of High-Impact Practices (HIPs) in an online learning environment. HIPs are "teaching and learning practices that have been widely tested and have been shown to be beneficial for college students from many backgrounds” (AAC\&U, 2013, p. 1). Kuh (2008) identified 11 HIPs as: capstone courses and projects, collaborative assignments and projects, common intellectual experiences, diversity/global learning, eportfolios, first year seminars and experiences, learning communities, internships, service and community-based learning, writing-intensive courses, and undergraduate research (pp. 9-11). Students who participate in at least one of the HIPs spend more time preparing for class and interact more frequently with their instructors about substantive matters (Watson et al., 2016). HIPs have been used to study student success (McGlynn, 2014), engagement (Sweat, Jones, Han, \& Wolfgram, 2013), and the specific needs of first year students (Tukibayeva \& Gonyea, 2014) and those from traditionally underrepresented backgrounds (Sweat et al., 2013). Benefits from HIPs are impressive and include increased rates of student persistence, higher Grade Point Averages (GPAs), and improved student engagement (Brownwell \& Swaner, 2010; Kinzie, 2012). Most importantly, Kuh (2008) reports a more pronounced positive relationship between HIPs and different measures of student learning achievement, such as GPAs and retention, for groups historically underrepresented in higher education. Indeed, Kuh (2008) recommends that students experience at a minimum one HIP in their first year and one while pursuing their major courses. He emphasizes that ideally students should experience a HIP every year.

One HIP of particular importance during this world-wide crisis is diversity/global learning. Often taking place within intercultural courses and programs, diversity/global learning is considered a HIP that encourages exploration of cultures, life experiences, and worldviews unlike students' own. Experiential learning in the community and/or study abroad are frequently used to augment these 
efforts. The temporary suspension of study abroad experiences and activities that involve students' interacting face-to-face with others, whether globally or within their own backyard, may feel like a door temporarily closed. However, the current situation does offer an opportunity, an open window if you will, for educators to embrace VE as a learning tool. Included under the diversity/global learning HIP category recognized by AAC\&U, VE uses technology to facilitate online, collaborative work among students and their peers in other countries. Importantly, VE offers a pedagogy that creates an international experience for large groups of students that might otherwise not experience global learning. As Abdel-Kader (2020) notes, "[t]his is not a time to abandon global learning. It is an imperative to continue to prepare students to contribute personally and professionally to the world they will inherit and lead, and VE makes this possible” (p. 3).

Although many consider VE a recent development, it originated in the late 1980's when United States and Soviet Union high school students connected online during the Cold War. VE also has a long history in foreign language where educators saw the strengths of connecting language learners with native speakers of other languages for a more genuine experience of communicating (O'Dowd, 2017). Foreign language educators and researchers have produced a huge body of research and practice literature investigating learning outcomes of students engaging in online collaborative activities (Belz, 2002, 2003; Hampel \& Hauck, 2006; Warschauer, 1996). VE also has strong roots in the area of Business Studies, especially in the disciplines of International Business and Marketing, and is often viewed as a means to prepare students to work with customers in other countries (O'Dowd, 2017). As the practice of VE emerged over the last several decades, projects are designed based on the needs and goals of the students, and no one model is considered the best or only way to engage in online intercultural exchanges. Thus, various models of VE have been implemented to create a substantive and engaging learning experience where students from different cultures work together. VE projects occur synchronously and asynchronously with trained educators implementing single course assignments, peer review, cooperative learning, online discussions, project-based learning, and/or service learning. Students typically engage in sustained communication over weeks or months to build trust with each other and understanding of different cultures.

The Stevens Initiative (2019), in its VE Impact and Learning Report, addresses some of the common challenges for implementing VE across programs, including allowing time for students to get to know one another, working around different time zones and academic calendars, balancing number of participants in different locations, maintaining participants' engagement, training facilitators adequately, and addressing language issues. Machwate et al. (2021) discuss an additional challenge of fostering reflection on perceived cultural differences between learners before setting up any VE project (p. 13). They suggest introducing students to Hofstede's (1984) model of cultural dimensions to learn about different cultures, discard stereotypes, and prompt communication and openness to 
respectful dialogue. Additionally, finding international partners and access to shared technologies often present problems in implementation, but Rubin, Dyba, and Tuke (2014) recognizes that there are a number of institutions providing support in these areas. O'Dowd (2021) notes the plethora of impact reports and publications providing examples of good pedagogical practices that address such challenges and result in multiple positive learning outcomes, such as the development of cultural knowledge, teamwork, flexibility, intercultural collaboration, and problem solving. Benefits of VE also include the development of digital competence (the ability to communicate and collaborate effectively online), teamwork, media literacy, and the ability to work in a diverse cultural context, all important employability skills (EVOLVE, n.d.).

While there are multiple benefits to VE, this research study focuses specifically on VE and students' development of intercultural effectiveness skills. Unfortunately, there is a good bit of conceptual ambiguity in the literature, and Fantini (2009) found numerous terms being used interchangeably, including "multiculturalism, cross-cultural adaptation, intercultural sensitivity, cultural intelligence, international communication, transcultural communication, global competence, cross-cultural awareness, and global citizenship" (p. 457). Generally, intercultural competence involves adapting behavior and communication to different settings through a variety of skills and knowledge (Bird, Mendenhall, Stevens, \& Oddou, 2010; Deardorff, 2011; Schaetti, Ramsey, \& Watanabe, 2009), and the more specific term Intercultural Communication Competence (ICC) is defined as "an individual's ability to achieve their communication goal while using appropriate communication behaviors to negotiate between different identities within a culturally diverse environment” (Portalla \& Chen, 2010, p. 23). According to Chen and Starosta (1996), intercultural effectiveness refers to intercultural adroitness or the behavioral aspect of ICC. In other words, intercultural effectiveness is "the ability to attain communication goals in intercultural interactions" (Portalla \& Chen, 2010, p. 22), and this is the definition used for the purpose of this study. With the modern wave of globalization, potential employers often view being able to communicate and work effectively across cultures as more important than a specific undergraduate major, and a survey of employers indicated $78 \%$ stressed the importance of all students gaining intercultural skills (Hart Research Associates, 2015).

Allport's (1954) Intergroup Contact Hypothesis, which posits that "contact between members of different groups (under certain conditions) can work to reduce prejudice and promote a more tolerant and integrated society" (pp. 2-3), provides the theoretical framework for this study. According to this theory, knowledge itself will not alter prejudices and stereotypes about others because people are likely to accept only the information that fits into their preconceived notion of the world. Instead, breaking down stereotypes is more likely to occur only through getting to know the other. In other words, the contact hypothesis claims that true acquaintance will lessen prejudice and bring about 
successful intergroup relations. However, the hypothesis specifies numerous conditions necessary for a successful contact, and while not all conditions need to occur simultaneously (Pettigrew \& Tropp, 2000), the more conditions that are co-present, the more effective the intergroup relations. Interestingly, Amichai-Hamburger and McKenna (2006) argue that interacting via the Internet provides many of the necessary conditions to support the Intergroup Contact Hypothesis, such as "creating a secure environment, reducing anxiety, cutting geographical distances, creating equal status, etc" (pp. 825-826). VE, where groups from different cultures interact via the Internet with the goal of building understanding and trust, has enormous potential for achieving effective intergroup contact.

While past research has often investigated the impact of one type of VE on intercultural skills in a particular academic area, (Commander et al., 2016; Custer \& Tuominen, 2017; Dorroll, Hall, Blouke, \& Witsell, 2019), no study to date goes beyond a single discipline to document that VE fosters intercultural skills of students studying in various disciplines while experiencing different types of VE activities. Importantly, the results of this study will provide information on the generalizability of VE and its suitability for providing wider access to international experiences for all students. Thus, this study takes a much needed broader look at the impact of VE in that participants are enrolled in classes that represent the areas of science, business, arts, social sciences, education, and public health. The primary objective is to measure the impact of various types of VE on students' development of intercultural effectiveness across disciplines.

In its annotated bibliography on VE research, the Stevens Initiative (2020) states that there is a dearth of research on international VEs involving underrepresented students. This study also explores the impact of VE on minority and non-minority participants' development of intercultural effectiveness. Research cites that underrepresented populations as a whole are less likely to participate in intercultural learning opportunities abroad (Luo \& Jamieson-Drake, 2015; Salisbury, Umbach, Paulsen, \& Pascarella, 2009) but are more likely to benefit from international experiences than their peers (Redden, 2012; Xu, de Silva, Neufeldt, \& Dane, 2013). Further, the Stevens Initiative (2020) states that many studies describe the number of hours spent engaging in virtual activities, or dosage, within a program, but they do not specifically research the effects of this variable. To address this gap, this study investigates the relationship between dosage and the development of students' intercultural effectiveness skills.

Our research questions are:

- What is the impact of VE on the development of intercultural effectiveness in students engaged in different disciplines? 
- What is the impact of VE on the development of intercultural effectiveness for minority and non-minority participants?

- What is the impact of VE dosage on the development of intercultural effectiveness skills?

\section{Methods}

\subsection{Participants}

Participants were 101 undergraduate and 30 graduate students $(\mathrm{N}=131)$ at a large research university in the Southeast region of the United States. Participants were selected because of their enrollment in one of eight courses identified as incorporating some form of VE into the curriculum. Students from five different colleges and one school enrolled in classes across disciplines and engaged in VE activities with students enrolled in 11 different international universities during the spring semester, 2020 (see Table 1). Seventy-four percent (N=97) selfidentified as female and $24 \%(\mathrm{~N}=32)$ self-identified as male, while two students chose not to respond to this question on the survey. Sixty-eight percent of participants $(\mathrm{N}=90)$ self-identified as an ethnic minority, 25\% ( $\mathrm{N}=33)$ self-identified as Caucasian, while eight students chose not to respond to this question on the survey. Additional self-reported demographic information is presented in Table 2.

\section{Table 1. VE projects across disciplines}

\begin{tabular}{|l|l|l|l|l|l|}
\hline Description of VE Project & Course & $\begin{array}{l}\text { Department/ } \\
\text { College }\end{array}$ & $\begin{array}{l}\text { Partner } \\
\text { Institution }\end{array}$ & US Students & Technology \\
\hline $\begin{array}{l}\text { Using the appropriate scholarly guidelines } \\
\text { of the writer's country (i.e. US or South } \\
\text { Africa), students engaged in peer } \\
\text { reviews of each other's manuscripts. }\end{array}$ & $\begin{array}{l}\text { Music } \\
\text { Teaching \& } \\
\text { Learning }\end{array}$ & $\begin{array}{l}\text { Music/College } \\
\text { of the Arts }\end{array}$ & $\begin{array}{l}\text { North-West } \\
\text { University, } \\
\text { South Africa }\end{array}$ & 6 & $\begin{array}{l}\text { Synchronous/ } \\
\text { asynchronous } \\
\text { video, text } \\
\text { chats }\end{array}$ \\
\hline $\begin{array}{l}\text { Students worked collaboratively to solve } \\
\text { real-world problems on the Agorize } \\
\text { open innovation challenge platform by } \\
\text { applying field-related technology. }\end{array}$ & $\begin{array}{l}\text { International } \\
\text { Business }\end{array}$ & $\begin{array}{l}\text { International } \\
\text { Business/ } \\
\text { Business }\end{array}$ & $\begin{array}{l}\text { ESCA-School of } \\
\text { Management, } \\
\text { Morocco }\end{array}$ & 16 & $\begin{array}{l}\text { Agorize } \\
\text { Platform: Real } \\
\text { Challenges }\end{array}$ \\
\hline $\begin{array}{l}\text { Students engaged in weekly discussions } \\
\text { about the role of critical language } \\
\text { in teacher education practices and } \\
\text { the importance of mastering second } \\
\text { language acquisition in praxis and } \\
\text { developing intercultural competence. }\end{array}$ & $\begin{array}{l}\text { Language and } \\
\text { Discourse }\end{array}$ & $\begin{array}{l}\text { Middle and } \\
\text { Secondary } \\
\text { Education/ } \\
\text { College of } \\
\text { Education } \\
\text { and Human } \\
\text { Development }\end{array}$ & $\begin{array}{l}\text { Izzet Baysal } \\
\text { University, } \\
\text { Turkey }\end{array}$ & 24 & $\begin{array}{l}\text { FlipGrid, } \\
\text { iCollege, } \\
\text { ThingLink, } \\
\text { Infogram, }\end{array}$ \\
Mindmeister \\
\end{tabular}




\begin{tabular}{|c|c|c|c|c|c|}
\hline $\begin{array}{l}\text { Students engaged in discussions and asked } \\
\text { and answered questions pertaining to their } \\
\text { thoughts, ideas, and feelings about topics } \\
\text { such as race and culture; how students } \\
\text { interacted with their family; and COVID-19 } \\
\text { and the shutdown. The students in Hong } \\
\text { Kong created commercials based on the } \\
\text { interests of the American students. The } \\
\text { American students created lesson plans } \\
\text { for instruction to address the ideas and } \\
\text { interests of their partners from Hong Kong. }\end{array}$ & $\begin{array}{l}\text { Diversity in } \\
\text { Educational } \\
\text { Contexts }\end{array}$ & $\begin{array}{l}\text { Education/ } \\
\text { Perimeter }\end{array}$ & $\begin{array}{l}\text { Education } \\
\text { University of } \\
\text { Hong Kong }\end{array}$ & 11 & $\begin{array}{l}\text { WebEx or } \\
\text { Skype }\end{array}$ \\
\hline $\begin{array}{l}\text { Students met bi-weekly to conduct } \\
\text { peer reviews and have discussions on } \\
\text { topics such as the cultural meanings } \\
\text { of food production, preparation, and } \\
\text { consumption; stereotypes of 'American' } \\
\text { and 'Japanese' food; food waste and } \\
\text { controversies; and global food movements. }\end{array}$ & $\begin{array}{l}\text { Global } \\
\text { Sociology } \\
\text { of Food }\end{array}$ & $\begin{array}{l}\text { Sociology/Arts } \\
\text { \& Sciences }\end{array}$ & $\begin{array}{l}\text { Osaka } \\
\text { University, } \\
\text { Japan }\end{array}$ & 16 & $\begin{array}{l}\text { Skype, Google } \\
\text { Doc, iCollege }\end{array}$ \\
\hline $\begin{array}{l}\text { Students engaged in video-based group } \\
\text { discussions and completed a module } \\
\text { on social and cultural attitudes about } \\
\text { disability in the US. They also watched } \\
\text { and responded to videos posted by the } \\
\text { students from Federal University of Alagoas } \\
\text { discussing social and cultural attitudes } \\
\text { about disability in Brazil. Students reflected } \\
\text { via video posts about the process of } \\
\text { interacting with individuals from another } \\
\text { country and culture and about their } \\
\text { reactions to partner students' responses. }\end{array}$ & $\begin{array}{l}\text { Disability and } \\
\text { Public Health }\end{array}$ & $\begin{array}{l}\text { Health Policy } \\
\text { \& Behavioral } \\
\text { Sciences/ } \\
\text { School of } \\
\text { Public Health }\end{array}$ & $\begin{array}{l}\text { University of } \\
\text { Pernambuco, } \\
\text { Recife, Brazil }\end{array}$ & 17 & $\begin{array}{l}\text { Flipgrid, } \\
\text { VoiceThread, } \\
\text { iCollege }\end{array}$ \\
\hline $\begin{array}{l}\text { Students engaged in cross-cultural } \\
\text { interactions on a blogging platform where } \\
\text { they wrote about topics of inclusion } \\
\text { and diversity related to the general } \\
\text { theme of leadership in the Sciences. }\end{array}$ & $\begin{array}{l}\text { Leadership } \\
\text { in Biology }\end{array}$ & $\begin{array}{l}\text { Biology/Arts } \\
\text { \& Sciences }\end{array}$ & $\begin{array}{l}\text { Ca’Foscari } \\
\text { University, } \\
\text { Venice Italy }\end{array}$ & 27 & $\begin{array}{l}\text { Blog Postings } \\
\text { and Discussion }\end{array}$ \\
\hline $\begin{array}{l}\text { Students used a blog to share thoughts } \\
\text { and ideas about education in different } \\
\text { countries; reviewed and discussed } \\
\text { education resources shared by partners; } \\
\text { and shared class projects with partners. }\end{array}$ & $\begin{array}{l}\text { Social Studies } \\
\text { Methods }\end{array}$ & $\begin{array}{l}\text { Early } \\
\text { Childhood and } \\
\text { Elementary } \\
\text { Education/ } \\
\text { College of } \\
\text { Education } \\
\text { and Human } \\
\text { Development }\end{array}$ & $\begin{array}{l}\text { Beijing } \\
\text { Normal } \\
\text { University, } \\
\text { China; Capital } \\
\text { Normal } \\
\text { University, } \\
\text { China; } \\
\text { National } \\
\text { Institute of } \\
\text { Education, } \\
\text { Singapore; } \\
\text { Seoul National } \\
\text { University, } \\
\text { South Korea }\end{array}$ & 14 & $\begin{array}{l}\text { iCollege, } \\
\text { WeChat, Zoom }\end{array}$ \\
\hline
\end{tabular}




\section{Table 2. Self-reported demographic information of participants $(\mathrm{N}=131)$}

\begin{tabular}{|l|l|l|}
\hline Characteristic & $\mathbf{n}$ & $\%$ \\
\hline Identify as an ethnic minority & 89 & 67.9 \\
\hline Between 20 and 29 years old, inclusively & 107 & 81.7 \\
\hline At or above 30 years old & 20 & 15.3 \\
\hline Participated in study abroad through a university & 19 & 14.5 \\
\hline Participated in extended international work travel a few months at a time & 8 & 6.1 \\
\hline Never worked or studied abroad & 66 & 50.3 \\
\hline Never lived in a foreign country & 77 & 58.8 \\
\hline Lived in at least one foreign country & 54 \\
\hline Fluently speaks at least one language other than English & 54.2 \\
\hline Consider themselves as bicultural & 54 & 41.2 \\
\hline Not permanent residents of the United States & 62 & 47.3 \\
\hline Nationalities represented & 17 & 13 \\
\hline & 16 & \\
\hline
\end{tabular}

\subsection{Materials}

This study focuses on what gains were made in students' intercultural competence as measured by the Intercultural Effectiveness Scale (IES) before and after participating in VE. Behrnd and Porzelt (2012) note, the "challenge of measuring intercultural competence is, besides the lack of a single commonly used definition, the assessment of not only knowledge and skills but also of attitudes and awareness” (p. 215). The IES, developed by the Kozai Group, evaluates competencies, attitudes, and awareness, all essential for effective interaction with people from different cultures and demographic backgrounds. In addition to a measure of overall intercultural competency, the IES divides the concept of intercultural effectiveness into six competencies and provides students with an in-depth graphic feedback profile of these specific areas (Mendenhall et al., 2012). Competencies measured by the IES are also in line with AAC\&U's (2010) VALUE rubric used to identify learning outcomes that both employers and faculty consider essential. In a 60 item survey that takes approximately ten minutes to complete, responses are made on a five-point Likert scale ranging from 'strongly disagree' to 'strongly agree'. The IES yields low, medium, or high scores on six key dimensions related to three major competency areas of continuous learning, interpersonal engagement, and hardiness. Each dimension has two subdomains: continuous learning is made up of self-awareness and exploration; interpersonal engagement is comprised of global mindset and relationship interest, while hardiness involves positive regard and resilience. The IES scores on continuous learning, interpersonal engagement, and hardiness are combination scores of their respective subdomains. Lastly, an overall IES score is generated by combining the results of the six 
subdomains. Mendenhall et al. (2012) provide a brief description of the three major competency areas and six key subdomains:

“Continuous Learning - How one learns about others and the accuracy of that learning:

- Self-Awareness - To what degree one is continuously learning about him/herself

- Exploration - To what degree one is open to different ideas, values, norms, situation, and behaviors

Interpersonal Engagement - How one develops and manages relationships with others who are different:

- World Orientation - To what degree one is interested in other cultures and the people who live in them

- Relationship Development - To what degree one initiates and maintains relationships with people from other cultures

Hardiness - How one manages the challenges and stress involved in interacting with those who present cultural and demographic differences:

- Positive Regard - To what degree one naturally assumes people are trustworthy

- Emotional Resilience - One's emotional strength and ability to cope with challenging emotional experiences” (pp. 7-12).

Berdrow and Bird (2018) present more detailed information on the major competency areas and dimensions.

Research indicates high reliability scores for the IES. Mendenhall et al. (2012) report factor analysis item loadings for each of the subscales of the three factors of continuous learning, interpersonal engagement, and hardiness, with an $\mathrm{N}$ of 2,308 that exceeds the minimum recommendation for a five-to-one subject-to-item ratio. The reliability scores for each of the subcategories or competencies in the IES all fall in the .76-.86 range. Continuous learning is reported to have an overall scale reliability of 0.85 with its two subscales of self-awareness and exploration yielding reliabilities of 0.76 and 0.82 respectively. Interpersonal engagement is reported to have an overall 
scale reliability of 0.86 with its two subscales of global mindset and relationship interest yielding reliabilities of 0.84 and 0.80 respectively. Hardiness is reported to have an overall scale reliability of 0.84 with its two subscales of positive regard and emotional resilience yielding reliabilities of 0.79 and 0.81 respectively.

Furthermore, the IES has been widely used in the literature on intercultural competence. Previous studies include exploring intercultural profiles of international graduate students (Robinson, Harrington, Cartwright, \& Walsh, 2017), pre- and post-test studies on globally focused on-campus courses (Feng, 2016; Fish, 2013), pre- and post-test research for semester long programs for Malaysian and international students (Gowindasamy, 2017), and institutional assessment of business school sophomores and seniors' intercultural effectiveness (Berdrow \& Bird, 2018). The IES has also been used as a pre- and post- measurement of intercultural effectiveness with freshmen enrolled in a global citizen course (Relvea, Guha, \& Fish, 2013), in Short Term Study Abroad (Nguyen, 2017; Quirk \& Gustafson, 2018), and to examine intercultural competency development in service experiences (Grass, 2014; Oberle, 2014). Individuals with higher scores on the IES often perform better on international assignments, transfer more of what they learn on foreign assignments when they return home, demonstrate higher levels of attachment and motivation related to work, and receive higher performance ratings by their supervisors (Furuya et al., 2009).

\subsection{Procedure}

Students completed the IES before and after participating in various VE projects to measure change in intercultural competencies. As in other models of VE (Starke-Meyerring \& Wilson, 2008, Chapter 1), the majority of VE projects in this study involved students working on shared subject content with students at a variety of international universities, often in the form of course modules, while learning about different cultural perspectives on the academic discipline they were studying. Students typically worked together to discuss content related to the course/ discipline, address a practical problem, and/or produce some type of gradable product. Interaction occurred asynchronously and/or synchronously while utilizing a variety of technology tools to communicate (See Table 1).

After completing the IES, each student received a 24-page self-report that included detailed results, common profiles with behavioral and attitudinal descriptors, guides to assist students with determining their profiles, and a development plan for self-improvement. In addition to students receiving their individual scores, a group administrator (the principle investigator on the study) received individual and group reports from the company Aperian Global, an international consultancy firm through which the IES was purchased. 


\section{Analysis and results}

Participants completed the same version of the IES before and after participating in VE activities. Two hundred and thirteen students took the pre-test, while 131 took the post-test, a retention rate of $61.5 \%$. The 82 students who did not take the post-test were excluded from the analysis, and the remaining 131 participants who took both pre- and post-tests form the sample for the analysis. In one course $(n=29)$, the post-test was not given at all due to the pandemic; the retention rate for other courses ranged from a low of $46 \%$ (six out of a total of 13) to a high of $100 \%$ (27 out of 27 ).

In response to Research Question 1, what is the impact of VE on the development of intercultural effectiveness in students engaged in different disciplines, raw scores from the IES data ranging from one to five based on a five-point Likert scale were analyzed. Each of the ten IES components was analyzed to determine what gains, if any, were made. Standard deviations and means were computed for overall IES scores. There are three main components and two subcomponents within each: continuous learning (self-awareness, exploration), interpersonal engagement (world orientation, relationship development), and hardiness (positive regard, emotional resilience), for a total of ten scores (Mendenhall et al., 2012, pp. 7-12). Descriptive statistics for pre-test and post-test for each factor and total scores, along with paired t-test results, are found in Table 3. As the table shows, post-test scores were higher for the overall test and for each subtest, though the gains were only statistically significant for the overall IES, continuous learning, self-awareness, interpersonal engagement, and world orientation. There were no differences in pre-test or gain scores when the data are disaggregated by individual classes or disciplinary areas.

Table 3. Descriptive statistics and paired t-test results for IES scores ( $N=131)$

\begin{tabular}{|l|l|l|l|l|l|}
\hline & \multicolumn{2}{l}{ Pre-test } & \multicolumn{2}{l|}{ Post-test } & Paired t (sig.) $^{\mathbf{a}}$ \\
\hline & M & SD & M & SD & \\
\hline Continuous Learning & 4.09 & 0.37 & 4.23 & 0.42 & $-4.763(.000)$ \\
\hline Self-Awareness & 3.93 & 0.42 & 4.13 & 0.45 & $-5.645(.000)$ \\
\hline Exploration & 4.26 & 0.39 & 4.34 & 0.39 & $-2.757(.007)$ \\
\hline Interpersonal Engagement & 3.53 & 0.50 & 3.70 & 0.55 & $-4.698(.000)$ \\
\hline World Orientation & 3.01 & 0.73 & 3.30 & 0.88 & $-5.509(.000)$ \\
\hline Relationship Development & 4.06 & 0.50 & 4.10 & 0.53 & $-.962(.338)$ \\
\hline Hardiness & 3.17 & 0.51 & 3.21 & 0.57 & $-1.193(.235) b$ \\
\hline Positive Regard & 3.22 & 0.55 & 3.26 & 0.65 & $-.754(.452)$ \\
\hline Emotional Resilience & 3.12 & 0.71 & 3.17 & 0.70 & $-.997(.321)$ \\
\hline Overall IES Score & 3.60 & 0.34 & 3.71 & 0.37 & $-4.574(.000)$ \\
\hline
\end{tabular}

${ }^{\mathrm{a}} \mathrm{df}=130$ except where indicated. $\mathrm{bdf}=129$ (one missing score). 
In response to Research Question 2, what is the impact of VE on the development of intercultural effectiveness for minority and non-minority participants, group differences were analyzed for ethnicity, based on the IES demographic survey, which asked students to identify as either 'ethnic minority' or 'White/Caucasian'. Independent $t$-tests of pre-test scores, using a Bonferroni correction for multiple comparisons, revealed no significant differences in pre-test scores, although four subtest scores (interpersonal engagement [ $t=-2.032, p=.044]$, relationship development [ $t=-2.437, p=.016]$, hardiness [ $t=-1.977, p=.048]$, and positive regard [ $t=-2.036, p=.044]$ ) did show a significant advantage for whites on the pre-test without this correction. There were, however, no significant differences in post-test scores or gain scores between the two groups.

In response to Research Question 3, what is the impact of VE dosage on the development of intercultural effectiveness skills, all groups showed gains on average. However, there is no clear relationship between dosage and gain scores, with at least as much variability within groups as between groups (see Table 4). The distribution of gain scores on the total test are arranged by the number of hours of exchange (dosage) for the eight courses. As the table shows, there is no clear relationship between the number of hours and scores and no trend line upwards. Groups that participated in VE for ten and 28 hours, respectively, did not gain as much, but results may be impacted by the quality of the exchange more than the quantity, and by the small $\mathrm{N}$ size of each group.

\section{Table 4. Relationship between dosage and IES scores}

\begin{tabular}{|l|l|l|l|l|l|}
\hline Course & Dosage & $\mathbf{n}$ & $\begin{array}{l}\text { Pre-test } \\
\text { mean (SD) }\end{array}$ & $\begin{array}{l}\text { Post-test } \\
\text { mean (SD) }\end{array}$ & $\begin{array}{l}\text { Gain score } \\
\text { mean (SD) }\end{array}$ \\
\hline Music Teaching \& Learning & 35 hours over 15 weeks & 6 & $3.43(.47)$ & $3.69(.57)$ & $.27(.44)$ \\
\hline International Business & 27 hours over 15 weeks & 16 & $3.74(.42)$ & $3.66(.41)$ & $-.07(.39)$ \\
\hline Language \& Discourse & 24 hours over 15 weeks & 24 & $3.73(.32)$ & $3.87(.31)$ & $.14(.20)$ \\
\hline Diversity in International Contexts & 20 hours over 15 weeks & 11 & $3.58(.26)$ & $3.79(.32)$ & $.14(.20)$ \\
\hline Global Sociology of Food & 13 hours over 2 weeks plus prep & 16 & $3.62(.30)$ & $3.81(.28)$ & $.19(.19)$ \\
\hline Disability \& Public Health & 10 hours over 10 weeks & 17 & $3.65(.29)$ & $3.67(.39)$ & $.01(.31)$ \\
\hline Leadership in Biology & 10 hours over 3 weeks & 27 & $3.50(.27)$ & $3.65(.39)$ & $.15(.32)$ \\
\hline Social Studies Methods & 7.5 hours over 5 weeks & 14 & $3.41(.40)$ & $3.56(.37)$ & $.14(.26)$ \\
\hline
\end{tabular}

\section{Discussion}

This study investigates VE as a promising HIP particularly appropriate for distance learning platforms. VE, which may be included under the diversity/global learning HIP recognized by AAC\&U, offers great promise as a practice that helps students explore cultures, life experiences, and worldviews different 
from their own. Due to the world health pandemic, higher education has shifted to an increased focus on how best to deliver engaging learning experiences to students online. This attention to virtual interactions via the Internet when the local and global interface is limited prompts educators to utilize technology and embrace VE as a powerful learning tool with multiple benefits to students. Indeed, Amichai-Hamburger and McKenna (2006) argue that interacting virtually via the Internet provides many of the necessary conditions to support Allport's (1954) Intergroup Contact Hypothesis, the theoretical framework for this study. Importantly, VE creates an international experience for large groups of students who might otherwise not experience global learning.

Following the call to examine the learning outcomes of VE in a variety of educational and cultural settings (Stevens Initiative, 2020), this study investigates the impact of various VE projects on the intercultural effectiveness skills of students enrolled in courses across disciplines. Data indicates that there were no differences in pre-test or gain scores when the data are disaggregated by individual classes or disciplinary areas. Thus, the increase in pre- and post-IES scores were not influenced by course enrollment or type of VE activities.

The response rate of $61.5 \%$ (131 out of 213 students completed both the pre- and post-IES scale) may reflect the difficulties experienced by faculties and students due to the pandemic. An informal final report requested from faculty included the question: "What was the impact of Covid-19 on implementing your VE project?”. Example responses describing the challenges and interruptions included the following.

"Coronavirus had a major impact because the partner university... closed almost at the end of the project period, when online discussion was picking up. Italy was one of the first countries to shutdown (the second after China), and the shutdown was sudden and unexpected, creating obvious stress and confusion. Therefore, the increased participation that I had anticipated by the end of the minimester did not occur".

"Spring 2020 was a very challenging semester due to the unexpected outbreak of Covid-19, global pandemic and school closure. I had to change my plan many times as international instructors and students had concerns about their schedule change, online transmission, personal and family safety/health issues, psychological stress/depression, and ideological/ political division/resentment as to the outbreak of the virus”.

"It interrupted our plans for student collaboration on the country research projects so that not all students were able to work well with their assigned partners, given the different time frames resulting from Turkey’s longer closing during the Covid-19 shift to online learning”. 
"Both students in Turkey and the US have negatively been influenced by the pandemic. They had restricted access to internet, and other familial and economic problems (e.g. losing jobs, death of relatives/parents, etc.)”.

In this study, we compared students' scores on the IES before and after engaging in VE activities, finding higher post-test scores for the overall test and for each subtest, and a statistically significant increase for the overall test and two of the three dimensions, continuous learning and interpersonal engagement. Respondents demonstrate an upward trend in intercultural competency as defined by their overall IES mean scores after participating in VE. While the full range possible is from 1.00 to 5.00, the mean scores for all ten IES components fell within the range of 3.01 and 4.34 (see Table 3).

As previously stated, the overall IES score is generated by combining the results of the six subdomains. Students were shown to have a starting mean score of 3.60 before participating in VE and a mean score of 3.71 afterwards. Although there was no control group for comparison, this movement suggests that overall IES scores are influenced by VE, i.e. participation in VE appears to positively impact the development of intercultural effectiveness as measured by the IES.

It is important to understand which dimensions impacted the change in overall IES scores. Significant gains were made in the continuous learning dimension, which reflects the degree to which you seek to understand and learn about activities, behavior, and events that occur around you, including your motivation to learn about why people in other cultures behave and think the way they do. It is interesting to note that this gain is strongly influenced by only one of the subdimensions, selfawareness. High scorers on self-awareness have a strong awareness of self and how they impact and affect others, as well as an openness to new ideas and experiences. Although only a small percentage of students indicated they had participated in international study abroad through a university and most had never lived in a foreign country (see Table 2), gains made on the dimension of continuous learning before and after engaging in VE may indicate an increased level of motivation to learn and experience new things in the future, such as study or living abroad.

Significant gains were also made on the dimension of interpersonal engagement, the factor that assesses one's interest in other cultures and importance of developing relationships with people from other cultures. The gain on this factor is strongly influenced by only one of the subdimensions in this area, world orientation. This subdimension measures the degree to which you are interested in other cultures and the people who live in them. Okayama, Furuto, and Edmonson (2001) recognize these characteristics of openness and curiosity about other cultures as attitudes fundamental to intercultural competence. High scorers in this area consistently expose themselves to information 
about cultures other than their own and are considered to have a strong global mindset. They often find topics and things in common that encourage discussions with people from other cultures (Berdrow \& Bird, 2018). These findings may reflect the 47.3 percentage of respondents who selfidentified as bicultural (see Table 2).

There were no significant gains on the dimension of hardiness, which measures one's ability to manage intercultural situations and view new ideas and behaviors with an open-mind and without judgment. Low scores on the subdimension of positive regard indicate a tendency to stereotype people and situations encountered in new cultures in order to make sense of the world. Low scores on the subdimension of emotional resilience may indicate a difficulty in handling psychologically and emotionally challenging experiences, and this may limit the ability to be open to others and learn from experiences in a foreign environment. While post-test scores were higher for positive regard and emotional resilience, the lack of significant movement from pre- to post-VE may be explained by models that view this type of strength and positivity as a part of an individual's attitude or predisposition that one's own worldview is not universal (Deardorff \& Hunter, 2006; Kim, 2001).

This study also explores the impact of VE on minority and non-minority participants' development of intercultural effectiveness. Since previous studies indicate underrepresented populations are more likely to benefit from international experiences than their peers (Redden, 2012; Xu et al., 2013), one might intuitively think that this would be the case with underrepresented students who experience VE. Although the majority of participants in this study self-identified as an 'ethnic minority' on the IES demographic survey, gains in the development of intercultural skills for this group were not significantly different from those who self-identified as 'White/Caucasian'. Although four subtest scores did show a significant advantage for whites on the pre-test, the gain scores between the two groups showed no differences. There is a dearth of research on VE involving underrepresented students, and more studies need to focus on how the experiences of minority students interacting with their international counterparts impact a multitude of factors, including intercultural skill development.

While the 2020 annotated bibliography on VE research (Stevens Initiative, 2020) notes that although studies often describe the length of VE programs and the number of hours spent engaging in VE activities, or what is known as 'dosage', there is little research on its impact. This study, however, investigated the effect of dosage on the development of intercultural skills. While all groups showed gains on average, there is no clear relationship between dosage and gain scores, with as much variability within groups as between groups. Future studies exploring dosage would provide much needed information on this important topic. 
One limitation of this study is the use of self-report data, often resulting in subjective responses and instances where subjects may select what they consider to be the more socially acceptable answer. Future research could evaluate development of intercultural effectiveness by combining both quantitative and qualitative data for multiple perspectives. Another limitation is the lack of control or comparison group in our research design. Given the various VE projects implemented across disciplines, matching a control group with the experimental group would have been difficult. Additionally, participant maturation or familiarity with the measurement instrument at the posttest may have contributed to the increase in intercultural effectiveness skills.

\section{Conclusion}

This study has important implications for both practitioners and program developers. Results highlight the generalizability of VE across disciplines and the impact of multiple types of VE projects on the development of students' intercultural competence. Results also indicate that VE is related to increased interest in other cultures and increased motivation to learn and experience new things. Importantly, our findings underline the suitability of VE for providing wider access to international experiences for all students. Thus, VE offers great promise as an effective HIP contributing to student success. Deardorff and Hunter (2006) note that neither language nor study abroad alone make students interculturally or globally competent. We agree and recognize the same is true for VE. While the world pandemic has focused higher education on virtual activities, campuses must embrace comprehensive programs to intentionally prepare global-ready graduates through multiple opportunities for international engagement. This study contributes to that effort in documenting VE as a strong option for developing students' intercultural effectiveness skills across disciplines.

\section{References}

AAC\&U. (2010). Intercultural knowledge and competence VALUE rubric. Association of American Colleges and Universities.

AAC\&U. (2013). High-impact educational practices: a brief overview. Association of American Colleges and Universities. http://www.aacu.org/leap/hip.cfm

Abdel-Kader, M. (2020, April 14). Harnessing technology for global education. Inside Higher Ed. https://www. insidehighered.com/views/2020/04/14/colleges-should-develop-more-virtual-exchange-programs-maintain-andincrease-global

Allport, G. W. (1954). The nature of prejudice. Addison-Wesley. 
Amichai-Hamburger, Y., \& McKenna, K. Y. A. (2006). The contact hypothesis reconsidered: interacting via the internet. Journal of Computer-Mediated Communication, 11(3), 825-843. https://doi.org/10.1111/j.10836101.2006.00037.x

Behrnd, V., \& Porzelt, S. (2012). Intercultural competence and training outcomes of students with experiences abroad. International Journal of Intercultural Relations, 36(2), 213-223.

Belz, J. A. (2002). Social dimensions of telecollaborative foreign language study. Language Learning \& Technology, $6(1), 60-81$.

Belz, J. A. (2003). Linguistic perspectives on the development of intercultural competence in telecollaboration. Language Learning \& Technology, 7(2), 68-99. https://doi.org/10125/25201

Berdrow, I., \& Bird, A. W. (2018). Development and assessment of intercultural effectiveness: a learner-centered approach. Journal of Education, 198(2), 135-145.

Bird, A., Mendenhall, M., Stevens, J. J., \& Oddou, G. (2010). Defining the content domain of intercultural competence for global leaders. Journal of Managerial Psychology, 25(8), 810-828.

Brownwell, J. E., \& Swaner, L. E. (2010). Five high-impact practices: research on learning outcomes, completion, and quality. Association of American Colleges \& Universities.

Chen, G. M., \& Starosta, W. J. (1996). Intercultural communication competence: a synthesis. Communication Yearbook, 19, 353-383.

Commander, N. E., Ku, K. Y. L., Ashong, C., Gallagher, P., Deng, L., \& Li, S. (2016). Cross-national online discussions with U.S. and Hong Kong education students. Journal of Technology and Teacher Education, 24(4), 5-35.

Custer, L., \& Tuominen, A. (2017). Bringing 'internationalization at home' opportunities to community colleges: design and assessment of an online exchange activity between US and Japanese students. Teaching Sociology, 45(4), 347-357.

Deardorff, D. K. (2011). Assessing intercultural competence. New Directions for Institutional Research, 149, 65-79.

Deardorff, D. K., \& Hunter, W.E. (2006). Educating global-ready graduates. International Educator, 15(3), 72-83.

Dorroll, C., Hall, K., Blouke, C., \& Witsell, E. (2019). Virtual exchange pedagogy. Journal of Comparative \& International Higher Education, 11(1), 3-10. https://doi.org/10.32674/jcihe.v11iSpring.925

EVOLVE. (n.d.). What is virtual exchange? Evidence-Validated Online Learning through Virtual Exchange. https:// evolve-erasmus.eu/about-evolve/what-is-virtual-exchange/

Fantini, A. (2009). Assessing intercultural competence: issues and tools. In D. K. Deardorff (Ed.), The SAGE handbook of intercultural competence. Sage.

Feng, J. B. (2016). Improving intercultural competence in the classroom: a reflective development model. Journal of Teaching in International Business, 27(1), 4-22.

Fish, K. (2013). Increasing intercultural effectiveness through a global citizenship approach. Administrative Issues Journal, 3(3), 15-18.

Furuya, N., Stevens, M., Bird, A., Oddou, G., \& Mendenhall, M. (2009). Managing the learning and transfer of global management competence: antecedents and outcomes of Japanese repatriation effectiveness. Journal of International Business Studies, 40(2), 200-215. 
Gowindasamy, M. (2017). A case study on the implementation of reflective development model in improving intercultural competence among business student in Stamford College. Journal of Education and Practice, 8(12), 168-174.

Grass, S. (2014). An evaluation of an international service experience and students' intercultural competence. Unpublished doctoral dissertation. Florida State University.

Hampel, R., \& Hauck, M. (2006). Computer-mediated language learning: making meaning in multimodal virtual learning spaces. JALT-CALL Journal, 2(2), 3-18.

Hart Research Associates. (2015). Falling short? College learning and career success [Selected findings from online surveys of employers and college students conducted on behalf of the Association of American Colleges \& Universities].

Hofstede, G. (1984). Culture's consequences: international differences in work-related values (2nd ed.). Sage Publications. Kim, Y. Y. (2001). Becoming intercultural: an integrative theory of communication and cross-cultural adaptation. Sage Kinzie, J. (2012). High-impact practices: promoting participation for all students. Diversity and Democracy, 15(3).

Kuh, G. D. (2008). High-impact education practices: what are they, who has access to them, and why they matter. Association of American Colleges and Universities.

Luo, J., \& Jamieson-Drake, D. (2015). Predictors of study abroad intent, participation, and college outcomes. Research in Higher Education, 56(1), 29-56. https://doi.org/10.1007/s11162-014-9338-7

Machwate, S., Bendaoud, R., Henze, J., Berrada, K., \& Burgos, D. (2021). Virtual exchange to develop cultural, language, and digital competencies. Sustainability, 13(11), 5926. https://doi.org/10.3390/su13115926

McGlynn, A. P. (2014). Report shares high-impact practices for student success. Hispanic Outlook in Higher Education Magazine, 24(12). https://www.wdhstore.com/hispanic/data/pdf/march24-ccsse.pdf

Mendenhall, M. E., Stevens, M. J., Bird, A., Oddou, G. R., \& Osland, J. S. (2012). Intercultural effectiveness scale technical report. The Kozai Group, Inc.

Nguyen, A. (2017). Intercultural competence in short-term study abroad. Frontiers: The Interdisciplinary Journal of Study Abroad, 29(2), 109-127.

O’Dowd, R. (2017). Virtual exchange and internationalizing the classroom. Training Language and Culture, 1(4), 8-24.

O'Dowd, R. (2021). Virtual exchange: moving forward into the next decade. Computer Assisted Language Learning, 34(3), 209-224. https://doi.org/10.1080/09588221.2021.1902201

Oberle, L. A. (2014). The impact of international versus domestic service-learning experiences on college students' intercultural competence. Unpublished dissertation. Gannon University.

Okayama, C., Furuto, S., \& Edmonson, J. (2001). Components of cultural competence: attitudes, knowledge, and skills. In R. Fong \& S. Furuto (Eds), Culturally competent practice: skills, interventions, and evaluations (pp. 89-100). Allyn \& Bacon.

Pettigrew, T. F., \& Tropp, L. R (2000). Does intergroup contact reduce prejudice? Recent meta-analytic findings. In S. Oskamp (Ed.), Reducing prejudice and discrimination: social psychological perspectives (pp. 93-114). Erlbaum.

Portalla, T., \& Chen, G. (2010). The development and validation of the intercultural effectiveness scale. Intercultural Communication Studies, 19(3), 21-37. 
Quirk, S., \& Gustafson, J. (2018). Developing the next generation of global leaders: proposing an iterative framework for student global leadership development. https://doi.org/10.1108/S1535-120320180000011008

Redden, E. (2012, July 10). New studies link education abroad to on-time graduation. Inside Higher Ed. https://www. insidehighered.com/print/news/2012/07/10/new-studies-link-study-abroad-time-graduation

Relvea, C., Guha, G. S., \& Fish, K. (2013). Increasing intercultural effectiveness through a global citizenship approach. Administrative Issues Journal, 3(3), Article 9.

Robinson, J., Harrington, M., Cartwright, C., \& Walsh, K. (2017). Connective leadership: from zero-sum to inclusion. In A. Boitano, R. L. Dutra \& H. E. Schockman (Eds), Breaking the zero-sum game: transforming societies through inclusive leadership (pp. 209-225). Emerald Publishing Limited.

Rubin, J., Dyba, N., \& Tuke, G. (2014, September 12). An introduction to collaborative online international learning [Conference session]. Plenary of 1st Global Engagement through Technology Symposium, Bothell, WA, United States.

Salisbury, M. H., Umbach, P. D., Paulsen, M. B., \& Pascarella, E. T. (2009). Going global: understanding the choice process of the intent to study abroad. Research in Higher Education, 50(2), 119-143. https://doi.org/10.1007/s11162-008-9111-x

Schaetti, B. F., Ramsey, S. J., \& Watanabe, G. C. (2009). From intercultural knowledge to intercultural competence: developing an intercultural practice. In M. S. Moodian (Ed.), Contemporary leadership and intercultural competence: exploring the cross-cultural dynamics within organizations (pp. 125-144). Sage.

Starke-Meyerring, D., \& Wilson, M. (2008). (Eds). Designing globally networked learning environment: visionary partnerships, policies, and pedagogies. Sense Publishers. https://doi.org/10.1163/9789087904753_002

Stevens Initiative. (2019). Virtual exchange impact and learning report 2019. The Aspen Institute. https://www. stevensinitiative.org/wp-content/uploads/2019/11/Virtual-Exchange-Impact-and-Learning-Report.pdf

Stevens Initiative. (2020, February). 2020 Annotated bibliography on virtual exchange research. The Aspen Institute. https://www.stevensinitiative.org/wp-content/uploads/2020/02/2020-Annotated-Bibliography-on-Virtual-ExchangeResearch.pdf

Sweat, J., Jones, G., Han, S, \& Wolfgram, S. M. (2013). How does high impact practice predict student engagement? A comparison of white and minority students. International Journal for the Scholarship of Teaching and Learning, 7(2), 17.

Tukibayeva, M., \& Gonyea, R. M. (2014). High-impact practices and the first-year student. New Directions for Institutional Research, 2013(160), 19-35.

Warschauer, M. (1996). Comparing face-to-face and electronic discussion in the second language classroom. CALICO Journal, 13(2), 7-26.

Watson, C. E., Kuh, G. D., Rhodes, T., Light, T. P., \& Chen, H. L. (2016). Editorial: ePortfolios - the eleventh high impact practice. International Journal of ePortfolio, 6(2), 65-69.

Xu, M., de Silva, C. R, Neufeldt, E., \& Dane, J. H. (2013). The impact of education abroad on academic success. An analysis of first-time students entering Old Dominion University, Virginia, 2000-2004. Frontiers: The Interdisciplinary Journal of Education Abroad, 23(1), 90-103. 


\section{Virtual Exchange?}

Published by University of Groningen Press | UGP, a not-for-profit press

Groningen, The Netherlands | UGP@rug.nl

(C) 2022 UNICollaboration (collective work)

(C) 2022 by Authors (individual work)

Journal of Virtual Exchange 2022

Edited by Carolin Fuchs and Müge Satar

Publication date: 2022/01/25

Journal of Virtual Exchange (JVE) is an online, open-access, peer-reviewed journal aimed at practitioners and researchers in the field known variously as virtual exchange, telecollaboration, or online intercultural exchange. It is the official journal of UNICollaboration (https://www.UNICollaboration.org/), the international academic organisation dedicated to supporting and promoting telecollaboration and virtual exchange in higher-level education.

Rights. The whole volume is published under the Attribution-NonCommercial-NoDerivatives 4.0 International licence (CC BY-NCND 4.0); individual articles may have a different licence. Under the CC BY-NC-ND licence, the volume is freely available online for anybody to read, download, copy, and redistribute provided that the author(s), editorial team, and publisher are properly cited. Commercial use and derivative works are, however, not permitted.

Disclaimer. University of Groningen Press does not take any responsibility for the content of the pages written by the authors of this article. The authors have recognised that the work described was not published before, or that it was not under consideration for publication elsewhere. While the information in this article is believed to be true and accurate on the date of its going to press, neither UniCollaboration nor University of Groningen Press can accept any legal responsibility for any errors or omissions. Additionally, the publisher makes no warranty, expressed or implied, with respect to the material contained herein. While University of Groningen Press is committed to publishing works of integrity, the words are the authors' alone.

Trademark notice. Product or corporate names may be trademarks or registered trademarks, and are used only for identification and explanation without intent to infringe.

Copyrighted material. Every effort has been made by the editorial team to trace copyright holders and to obtain their permission for the use of copyrighted material in this article. In the event of errors or omissions, please notify the publisher of any corrections that will need to by incorporated in future editions of this article.

Typeset by Research-publishing.net (https://research-publishing.net)

Noto fonts are open source. All Noto fonts are published under the SIL Open Font License, Version 1.1. Noto is a trademark of Google Inc. (https://www.google.com/get/noto/).

ISSN: 2647-4832 (online only)

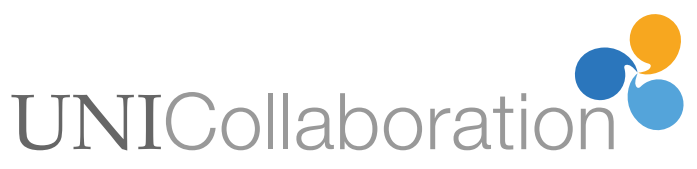

